\title{
LEVEL OF ANXIETY AND INCIDENCE OF HYPERTENSION IN ELDERLY AT GAPURANA VILLAGE TALANGO SUMENEP
}

\author{
Sri Sumarni1), Zakiyah Yasin2), Rifngatus Solekha ${ }^{3)}$ \\ 1,2) Lecturer of Faculty of Health Science, Wiraraja University \\ 3) Student of Faculty of Health Science, Wiraraja University \\ Corresponding e-mail : srisumarni73@yahoo.co.id, zakiyahfik@wiraraja.ac.id
}

\begin{abstract}
BACKGROUND : Hypertension is one of the most common diseases in developing countries such Indonesia. Some researcher said hypertension happens if after several measurements, the blood pressure value remained high, with systolic blood pressure $\geq 140 \mathrm{mmHg}$ and diastolic blood pressure $\geq 90 \mathrm{mmHg}$. Elderly people who have hypertension are at the big risk of experiencing anxiety compared to elderly people who don't have hypertension. The purpose of this study was to determine the relationship between anxiety levels and the incidence of hypertension on the elderly in Gapurana Village, Talango, Sumenep.
\end{abstract}

SUBJECT AND METHODE : Method of this research is Cross Sectional approach. The population in this study were all elderly who suffer from hypertension as many as 56 people and the sample of this study was elderly who suffer from hypertension with a total of 36 people, with the sampling technique using purposive sampling. The independent variable in this study is the levels of anxiety while the dependent variable is the incidence of hypertension on the elderly.

RESULTS : The results of the study between the levels of anxiety and the incidence of hypertension on the elderly showed that most of the elderly experienced mild anxiety are 20 people $(55.5 \%)$ and most of the elderly suffered stage 1 of hypertension are 20 people (55.5\%). The results of statistical tests using the Spearman Test obtained $\rho$ value $=0,000(\rho<50.05)$, so $\mathrm{H}_{\mathrm{o}}$ was rejected and $\mathrm{H}$ I was accepted, which that means there was a relationship between anxiety levels and the incidence of hypertension on the elderly in Gapurana Village, Talango.

DISCUSSION : Therefore, the elderly who suffer from hypertension and experience anxiety, should be more responsive in controlling hypertension by maintaining a healthy lifestyle and also interacting with the surrounding environment so that they do not always feel anxious about their condition about health problems.

\section{Keywords: Anxiety, Hypertension Incidence.}

\section{INTRODUCTION}

Elderly is an individual aging process marked by increasing age that make a changing in organ function such as brain, heart, liver and kidney and at the same time tissue disfunctions are increase. The number of elderly in Indonesia is increasing which means that it will bring seious problems physically or psychosocially. Individual are said to be elderly if they are 65 or older. Old age is not a problem, but it is a life proccess characterized by body disfunction to adapt to the social environment. An old age are said to be the final stage of life. Everyone will experienced the so-called aging process and the body function can not run normally.

Elderly who experience health problems will cause unexplained fears continously, making them think that they are no longer able to do their daily activity that will make them feel disturbed, lonely, sad, depressed, affraid or even anxious. Anxiety is a mental health problem that is often arises for individual, especially in the elderly. Fear and anxiety in the elderly will indirectly lead to psychological problems, where the elderly will feel stressed about their condition so that it can cause new, more serious problems such as hypertension which is more common in elderly. 
Hipertension is common in elderly.hypertension is also known as silent killer with unkown etiology. Hypertension or high blood pressure is a condition of individuals who have a history of blood pressure above normal, causing the risk of morbidity and mortality.

According to the data from World Health Organization (WHO), there were aboet 972 million of people or $26.4 \%$ people are suffering hypertension worldwide. This number is likely to increase to $19.2 \%$ in 2025 . There were 333 million people with hypertension who ived in developed countries, including Indonesia. The prevalence of hypertension increases with age. The number are increase as much as $7 \%$ at age $25-34$ years old, $16 \%$ at age $33-44$ years old and increasing reach to $29 \%$ in the age 60 years or more (WHO, 2011).

Based on the data of Riskesdas on east Java the prevalence of hypertension reached $26.2 \%$. The highest prevalence of hypertension is found in the age older than 75 years old as much as $62.4 \%$ (BPPK Ministry of Health, 2013). Prevalence of hypertensionin elderly in Sumenep in 2014 were 17,621 people with highest prevalence at the age $60-69$ years old. Based on the in 2017 at the Puskesmas Talango there were about 118 people with hypertension aged 45-59 years old, while for people aged 60 years ald over as many as 171 people.

Based on preliminary surveys conducted during interviews in the village of Gapurana, Talango District, out of 10 elderly people who have hypertension, there are 5 elderly people who say that they are more sensitive, irritable, dizzy, easily offended by other people's words, and there are 3 elderly always asking about his current illness. Besides that, there were 2 elderly people who said that they were fien with their illnesses so they did not take their illness seriously. Elderly with hypertension often experienced anxiety, because they though they could not accompllish their daily activitu as usual.

Anxiety is very influential in the elderly with hypertension, since it cause narrowing blood vessels so that the blood pressure is increase and exceed the normal limit. About $90 \%$ etiology of hypertension is unknown and it is known as essential hypertension. Eventhough the etiology is nown, there are several theories says that hypertension is caused by genetic factors, hormonal changes and sypmathetic changes. While secondary hypertention refer to hypertension caused by health problem or certain disease (Arif Muttaqin, 2009).

Elderly's health status will return to narmal if the elderly could manage the etiologic factors. However psychological factors are significantly affected the preventing process of hypertension. Physcisl ability will frightened the elderly and culd make them feel anxious since the illness suffered cannot be cured as before and even worsened and the hope for recovery is decreasing. As the elderly getting anxious they will feel uncomfortable, affraid and even panic and starting to thingking negatively about surrounding environment.

Hypertension in elderly can be minimized by avoiding the factors that can lead to hypertension such as regulating healthy life style and eating patterns, regulating weight loss, limiting alcohol, sodium, tobacco, reducing excessive salt consumptions and exercise to reduce anxiety. Anxiety in elderly could relieve by doing some relaxation technicque like breathing exercise which is conduct to reducing anxiety and also music therapy in order to make them fell peaceful and more prosperous (Arif Muttaqin, 2009).

Based on the interview and finding about the incidence of hypertension in Gapurana village Talango district, the researcher are interest in conducting study " Correaltion Between Anxiety Level and The Incidence of Hypertension in Gapurana village, Talango district Sumenep. The study is expected to be one of the efforts ti prevent or reduce anxiety level in the elderly with hypertension and maintain quality of life of the elderly.

\section{METHODE}

This study is analytical study conduct with cross sectional approach. The study involving 36 respondents taken by purposive sampling. The data were taken by questionnaire then analyzed by Spearman rho statistical test. 


\section{RESULT AND DISCUSSION}

Gapurana village is one of 8 villages or subdictrict which is located in the east of the Talango District area. The boundaries of the Gapurana Village in the Talango District are as follows :

1. North side : bordering the sea

2. East side : boredering Palasa Village

3. Southern side : bordering Cabbiya Village and Essang Village

4. West side : bordering the village of Talango

The distance to the capital district is about $5 \mathrm{~km}$ and the total area of Gapurana Village is 894,489 ha.

Tabel 1.Respondent's Characteristic in Gapurana Village Talango District Sumenep (April, 2019)

\begin{tabular}{|c|c|c|}
\hline Characteristic & Frequency & Percentage (\%) \\
\hline \multicolumn{3}{|l|}{ Age (years old) } \\
\hline $61-63$ & 12 & 33,3 \\
\hline $64-66$ & 11 & 30,5 \\
\hline $67-69$ & 3 & 8,3 \\
\hline $70-72$ & 2 & 5,5 \\
\hline $73-75$ & 2 & 5,5 \\
\hline $76-78$ & 6 & 16,6 \\
\hline \multicolumn{3}{|l|}{ Gender } \\
\hline Male & 9 & 25 \\
\hline Female & 27 & 75 \\
\hline \multicolumn{3}{|l|}{ Marital Status } \\
\hline Single & 0 & 0 \\
\hline Married & 36 & 100 \\
\hline \multicolumn{3}{|l|}{ Educational Level } \\
\hline Uneducated & 24 & 66,6 \\
\hline Elementary school & 12 & 33,3 \\
\hline \multicolumn{3}{|l|}{ Occupation } \\
\hline Unocupied & 5 & 13,8 \\
\hline Trader & 10 & 27,7 \\
\hline Farmer & 21 & 58,3 \\
\hline Total & 36 & 100 \\
\hline
\end{tabular}

According to the data the result study show that majority of respondents experiencing mild anxiety. This condition is affected by respondents occupational status. According to the table 1 it can be seen that most respondents work as farmer. Working as a farmer making the respondents feel no worry about their life because their energy is spent to do their activity on a farm. The activity could distract them from anxiety.

Previous study conducted by Octavianus (2018) titled "Correlation of Hypertension and Level Anxiety in Elderly in Eldelry Health Center in Bajarejo Ngantang, Malang" revealed that $51 \%$ repondents has moderate anxiety, $36.1 \%$ has mild anxiety and $13,9 \%$ has severe anxiety.

Researcher opinion stated that anxiety experienced by the elderly in Gapurana is due to the ignorance about the illness so that they keep thinking about and questioning the health problem that are coming to occur. Occupation and age are belief to become the etiology of anxiety. Individuals whose age is 60 years and over, it is definitely experiencing their inability to socialize with the surrounding environment, causing the elderly to be depressed and silent. This situation will make them feel fear and anxiety. 
Table 2. Correlation Between Level of Anxiety and Incidence of Hypertension In Elderly at Gapurana Village (April, 2019)

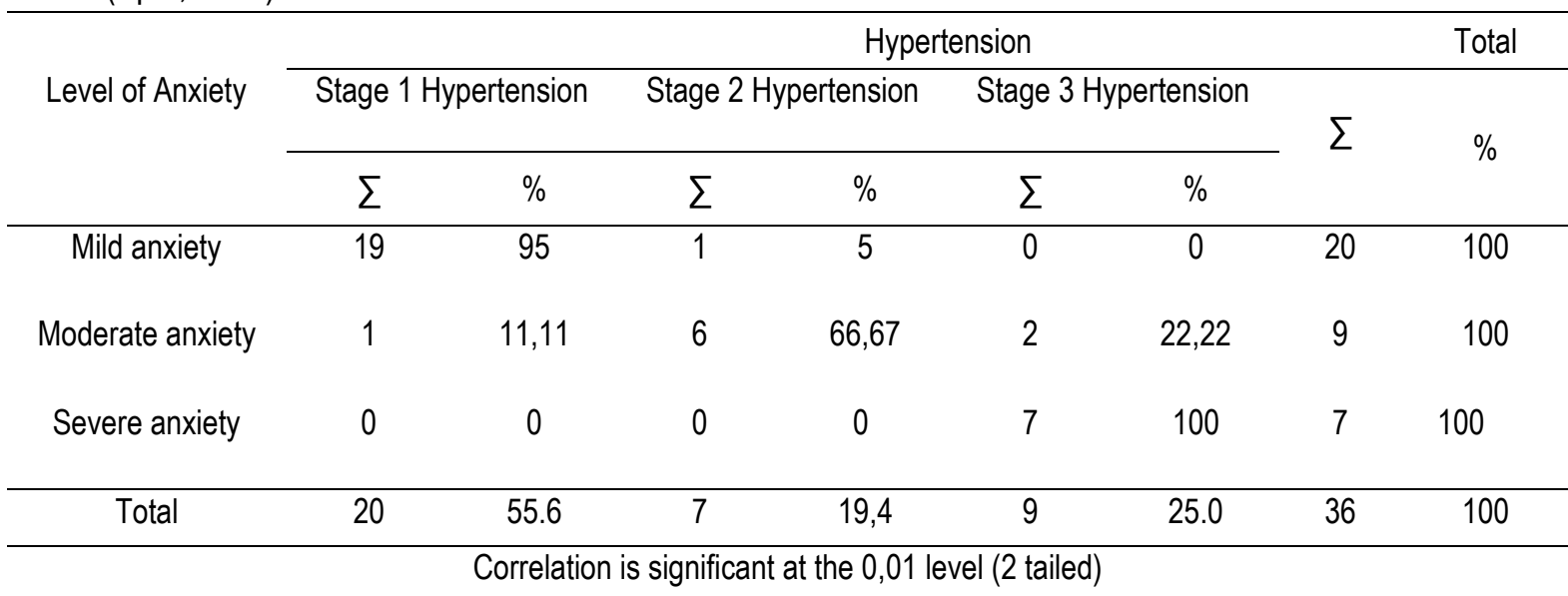

The elderly who experience problems like that feel confused about the condition. So the researcher suggest the elderly to do more activity outside such as helping other elderly who are farming, looking for the cows that are being raised so that the health problem that occur and cause anxiety does not always hunt.

According to the data of result study 55,6\% respondents are experiencing stage 1 hypertension. Hypertenision of elderly in Gapurana is most likely influenced by factor such as the age since it can be seen from blood pressure observation that elderly with hypertension are likely 61-63 years old.

Hypertension is silent killer. It can trigger other disease such as stroke, heart disease and kiney failure that lead to mortality. Blood pressure will arise as individuals get older. Individuals age 60 yeasr old and above, usually has blood pressure higher or equal to $140 / 90 \mathrm{mmHg}$.

Previous study conducted by Octavianus (2018) titled "Correlation of Hypertension and Level Anxiety in Elderly in Eldelry Health Center in Bajarejo Ngantang, Malang" show that q5 respondents is having stage 2 hypertension, 13 respondents is having stage 1 hypertensionand 8 elderly is having stage 3 hypertension.

It is assume that hypertension of elderly in Gapurana is due to the age and unhealthy life style. As the people get older the blood pressure is arisedue to decreasing of organ function and become abnormal s it lead to hypertension. Unhealthy lifestyle is also lead to hypertension. Lifestyle management such as doing body exercise, stop smoking, stop drinking alcohol and limited salty food could minimize hypertension.

According to the data it is show that elderly with mild anxiety most of them are having stage 1 hypertension and the blood pressure is counted $140 / 90 \mathrm{mmHg}$. It can be conclude that anxiety could affect elderly with hypertension. Statistical analysis spearman correlation show significancy $p$ value $0.000(p<a 0.05)$ means that Ho is rejected and $\mathrm{H} 1$ accepted and it can be conclude that there is a significant correlation between anxiety level and incidence hypertension in elderly. Coefficient correlation show value of 0.920 means that correlation between anxiety level and incidence of hypertension is strong.

Previous study conducted by Octavianus (2018) titled "Correlation of Hypertension and Level Anxiety in Elderly in Eldelry Health Center in Bajarejo Ngantang, Malang" show that level of axiety can affect the hypertension. Level of anxiety is not only affected by hypertension but also th eother factors as well. In this study the eldrdly with stage 2 hypertention are having moderate anxiety.

The anxiety experienced by the elderlycpuld be minimixe by looking for activities outdise such as filling free time by working or doing activities they like. So as to reduce the level of hypertention the elderly are asked to fulfil their timeby working or do their favourite activity. It will reduce the anxiety. And forget what happen to them. 
Hypertension in eldelry is also minimize by doing some physycal exercise. It will help the elderly to lowering thier blood pressure. The other way to lowering blood pressure is by doing relaxation. Relaxation will help the elderly to not thinking over their condition.

\section{CONCLUTION AND RECOMMENDATION}

Most of eldelry in Gappurana are having mild anxiety and stage 1 hypertension. The statistical analysis show that corraltion between level anxiety and hypertension. So it is recommended that the elderly should lowering the anxiety they experienced by having conversation with family and good friend.

\section{REFERENCE}

Adisti S. Psi., Prisna. 2010. Personality Plus For Teens. Yogyakarta: Pustaka Grhatama.

Annas, Budi. 2017. Hubungan antara Tingkat Stres dan Kecemasan dengan Kejadian Hipertensi pada Lansia di Klinik Islamic Center Samarinda. Jurnal IImu Kesehatan. Vol. 5 No. 1.

Az-Zahrani, Dr. Musfir bin Said. 2005. Konseling Terapi. Jakarta: Gema Insani Press.

Candra, Wawan. 2017. Psikologi Landasan Keilmuwan Praktik Keperawatan Jiwa. Yogyakarta: ANDI.

Elisa, Diana dkk. Bebas Hipertensi dengan Terapi Jus. Jakarta: Pustaka Pembangunan Swadaya Nusantara.

Epiphania, Agnes. 2018. Gambaran Tingkat Kecemasan Pada Lansia Dengan Hipertensi Di Puskesmas Nita Kabupaten Sikka. Nusa Tenggara Timur: Progam Studi Keperawatan Universitas Hasanuddin.

Ferry, Efendi. 2009. Keperawatan Kesehatan Komunitas: Teori dan Praktik dalam Keperawatan. Jakarta: Salemba Medika.

Hidayah, Nur. 2014. Landasan Sosial Budaya Dan Psikologis Pendidikan. Malang: Penerbit Gunung Samudra.

Illiyini. 2017. Hubungan Tingkat Pengetahuan dengan Perilaku Cuci Tangan Menggunakan Handrub pada Keluarga Pasien di Ruang Bedah RSUD dr. H. Moh. Anwar Sumenep. Skripsi. Sumenep. Universitas Wiraraja.

Indra. 2018. Hubungan Kecemasan dengan Kejadian Hipertensi pada Lansia di Desa Kedopok Kecamatan Kedopok Kota Probolinggo. Skripsi. Jombang. Sekolah Tinggi Ilmu Kesehatan.

Junaedi, Edi. 2013. Hipertensi Kandas Berkat Herbal. Jakarta: FMedia (Imprint AgroMedia Pustaka).

Kadek, Devi. 2016. Hubungan Tingkat Kecemasan dengan Kejadian Hipertensi di Panti Sosial Tresna Werdha Senjarawi Bandung. Jurnal IImu Keperawatan. Vol. IV No. 2.

Maryam, Siti dkk. 2008. Mengenal Usia Lanjut dan Perawatannya. Jakarta: Salemba Medika.

Meihartati, Tuti dkk. 2018. 1000 Hari Pertama Kehidupan. Yogyakarta: CV. Budi Utama.

Muhidh, Abdul. 2016. Pendidikan Keperawatan Gerontik. Yogyakarta: CV. Andi Offset.

Muttaqin, Arif. 2009. Pengantar Asuhan Keperawatan Klien dengan Gangguan Sistem Kardiovaskular. Jakarta: Salemba Medika. 
Notoatmodjo, Soekidjo. 2010. Metodologi Penelitian Kesehatan. Jakarta: Rineka Cipta.

Octavianus, Klaudius Laka. 2018. Hubungan Hipertensi dengan Tingkat Kecemasan pada Lansia di Posyandu Lansia Desa Banjarejo Kecamatan Ngantang Malang. Jurnal: Volume 3 Nomor 1.

Saputro, Heri. 2017. Anak Sakit Wajib Bermain di Rumah Sakit: Penerapan Terapi Bermain Anak Sakit Proses,Manfaat dan Pelaksanaannya. Ponorogo: Forum Ilmiah Kesehatan (FORIKES).

Simbolon, Demsa. 2016. Deteksi Dini Faktor Risiko Penyakit Tidak Menular (PTM). Yogyakarta: Budi Utama. 